Grzegorz KOWALECZKO ${ }^{1}$, Mariusz PIETRASZEK ${ }^{2}$, Łukasz SŁONKIEWICZ ${ }^{2}$

${ }^{1}$ Polish Air Force University (Lotnicza Akademia Wojskowa)

${ }^{2}$ Air Force Institute of Technology (Instytut Techniczny Wojsk Lotniczych)

\title{
ANALYSIS OF THE IMPACT OF THE TARGET ILLUMINATION TIME ON THE EFFECTIVENESS OF THE FLIGHT TRAJECTORY CORRECTION SYSTEM
}

\section{Analiza wpływu czasu podświetlania celu na efektywność układu korekcji lotu}

\begin{abstract}
This paper presents method of flight simulations for released laser guided bomb. Calculations were performed using six-degrees-of-freedom mathematical model of a bomb motion. Aerodynamics of the bomb was calculated using commercial software. Control laws were determined on the basis of signals detected by two pairs of laser sensors. Exemplary results of numerical calculations are submitted and conclusions focused on the main factors influencing on bombing accuracy are shown.
\end{abstract}

Keywords: exterior ballistics, guided munitions, flight control

Streszczenie: W pracy przedstawiono metode symulacji lotu bomby sterowanej laserowo. Obliczenia przeprowadzono za pomoca matematycznego modelu ruchu bomby o sześciu stopniach swobody. Aerodynamike bomby obliczono za pomoca komercyjnego oprogramowania. Sygnaty sterujace zostały określone na podstawie sygnałów wykrytych przez dwie pary czujników laserowych. Przedstawiono przykładowe wyniki obliczeń numerycznych i przedstawiono wnioski dotyczace głównych czynników wpływajacych na dokładność bombardowania.

Słowa kluczowe: balistyka zewnętrzna, amunicja kierowana, kontrola lotu 


\section{Description of the simulation model}

Simulation studies aimed to estimate how the activation time of the flight trajectory correction system affects the accuracy of the hit in the illuminated target. The calculations were done using a mathematical model of the movement of a guided bomb, which consists of the equations of movement supplemented by formulas defining control laws $[2,3,4,7,9]$.

The following designations are introduced:

- $U, V, W$-components of the bomb speed in $O x y z$ system associated with the bomb,

- $P, Q, R$ - angular velocity of the system associated with the bomb,

- $\Psi, \Theta$ i $\Phi-$ bomb angles defining its yaw, pitch and bank respectively,

- $x_{g}, y_{g}, z_{g}$ - coordinates of the location of the bomb relative to the Earth system $O_{g} x_{g} y_{g} z_{g}$.

- $m, I_{x}, I=I_{y}=I_{z}$ - mass and moments of inertia of the bomb.

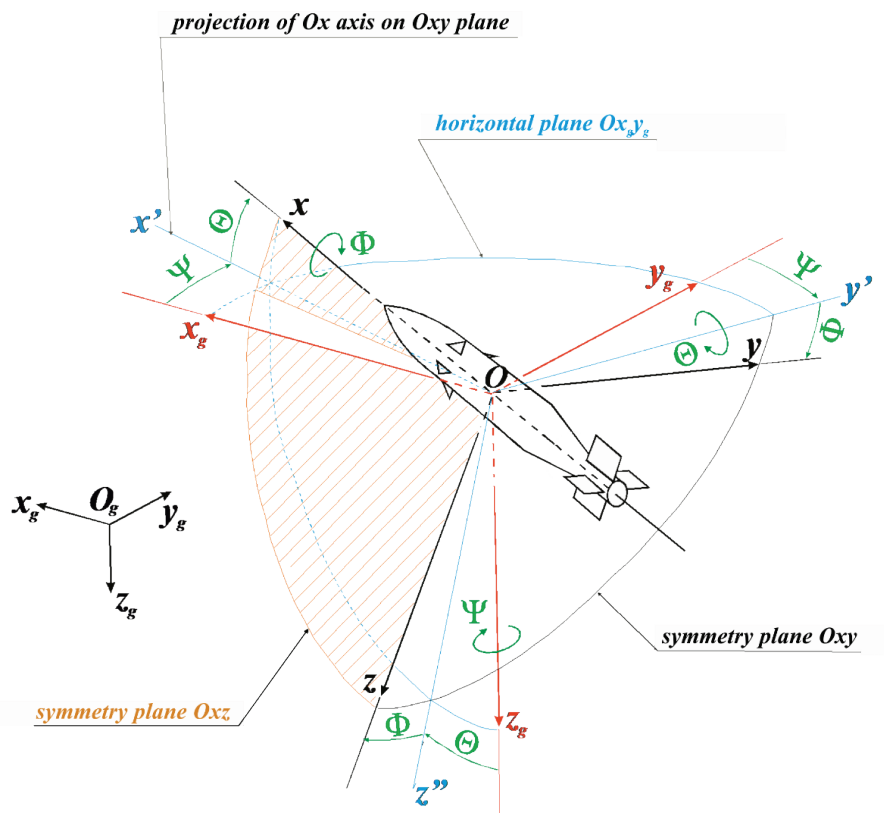

Fig. 1. Coordinate systems $\mathrm{Ox}_{\mathrm{g} g \mathrm{~g}} \mathrm{z}_{\mathrm{g}}$ and Oxyz

The movement of the bomb is described by the equations constituting the system of twelve differential equations:

$$
\mathbf{A} \dot{\mathbf{x}}=\mathbf{f}
$$


where $\mathbf{x}$ is the vector of flight parameters:

$$
\mathbf{x}=\left[U, V, W, P, Q, R, \Phi, \Theta, \Psi, x_{O}, y_{O}, z_{O}\right]^{T}
$$

Non-zero elements of matrix A amount to:

$$
\begin{aligned}
& A_{11}=m, A_{22}=m, A_{33}=m, \\
& A_{44}=I_{x}, A_{55}=I, A_{66}=I
\end{aligned}
$$

However, vector $\mathbf{f}$ is described as follows:

$$
\begin{gathered}
f_{1}=F_{x}+m(R V-Q W) \\
f_{2}=F_{y}+m(P W-R U) \\
f_{3}=F_{z}+m(Q U-P V) \\
f_{4}=M_{x} \\
f_{5}=M_{y}+P R\left(I-I_{x}\right) \\
f_{6}=M_{z}+P Q\left(I_{x}-I\right) \\
f_{7}=P+(Q \sin \Phi+R \cos \Phi) \tan \Theta \\
f_{8}=Q \cos \Phi-R \sin \Phi \\
f_{9}=(Q \sin \Phi+R \cos \Phi) / \cos \Theta \\
f_{10}=U \cos \Psi \cos \Theta+V(\cos \Psi \sin \Theta \sin \Phi-\sin \Psi \cos \Phi)+ \\
+W(\cos \Psi \sin \Theta \cos \Phi+\sin \Psi \sin \Phi) \\
f_{11}=U \sin \Psi \cos \Theta+V(\sin \Psi \sin \Theta \sin \Phi+\cos \Psi \cos \Phi)+ \\
+W(\sin \Psi \sin \Theta \cos \Phi-\cos \Psi \sin \Phi) \\
f_{12}=-U \sin \Theta+V \cos \Theta \sin \Phi+W \cos \Theta \cos \Phi
\end{gathered}
$$


The following forces act on the bomb: gravity force $\mathbf{Q}$, aerodynamic forces and aerodynamic moments. Fig. 2 presents a diagram of aerodynamic forces and moments. A precise method of their calculation was described in [4].

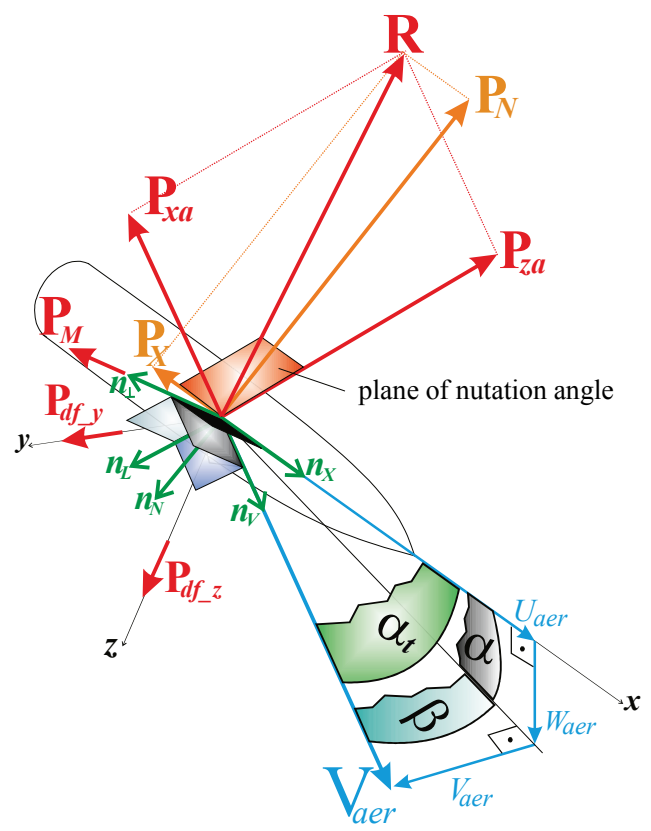

Fig. 2. Coordinate systems $\mathrm{Ox}_{\mathrm{g}} \mathrm{y}_{\mathrm{g}} \mathrm{Z}_{\mathrm{g}}$ and $\mathrm{Oxyz}$

- Gravity force has the following components:

$$
Q_{x}=-m g \sin \Theta, Q_{y}=m g \cos \Theta \sin \Phi, Q_{z}=m g \cos \Theta \cos \Phi
$$

The value of aerodynamic forces and moments is calculated from the following formulas:

- Axial force:

$$
P_{X}=C_{X} \frac{\rho\left|\mathbf{V}_{a e r}\right|^{2}}{2} S
$$

- Normal force:

$$
P_{N}=C_{N} \frac{\rho\left|\mathbf{V}_{a e r}\right|^{2}}{2} S
$$


- Statistical pitch moment:

$$
M_{s t}=C_{m_{-} s t} \frac{\rho\left|\mathbf{V}_{\text {aer }}\right|^{2}}{2} S d
$$

- Pitch-damping moment:

$$
M_{d m}=\left(C_{m_{-} q}+C_{m_{-} \dot{\alpha}}\right) \frac{\rho\left|\mathbf{V}_{a e r}\right|}{2} S d^{2}
$$

- Bank-damping moment:

$$
M_{p}=C_{p}\left(\frac{P d}{\left|\mathbf{V}_{a e r}\right|}\right) \frac{\rho\left|\mathbf{V}_{a e r}\right|^{2}}{2} S d
$$

The calculations used the characteristics of the bomb obtained during windtunnel studies, which were counted over taking into consideration the impact of the Mach number. To this end, the characteristics of the same bomb designated by the Prodas software were taken into account [8]. The basic relations used for the calculation of these characteristics in nutation angle $\alpha_{t}$ and control surfaces deflection angle $\delta_{F}$ are as follows:

- resistance coefficient:

$$
\begin{gathered}
C_{X}=C_{X 0}+C_{X \alpha 2}\left(\sin \alpha_{t}\right)^{2} \\
C_{X 0}=C_{X 0 \_W A T} \frac{C_{X 0 \_ \text {Prodas }}(M a)}{C_{X 0 \_ \text {Prodas }}(M a=0.01)}=\left(0.227+0.036 \frac{|\delta|}{15}\right) \frac{C_{X 0_{-} \text {Prodas }}(M a)}{C_{X 0 \_ \text {Prodas }}(M a=0.01)} \\
C_{X \alpha 2}=C_{X \alpha 2 \_W A T} \frac{C_{X \alpha 2 \_ \text {Prodas }}(M a)}{C_{X \alpha 2_{-} \text {Prodas }}(M a=0.01)}=\left[\left(6.59-0.15 \frac{|\delta|}{15}\right) \alpha^{2}\right] \frac{C_{X \alpha 2 \_ \text {Prodas }}(M a)}{C_{X \alpha 2 \_ \text {Prodas }}(M a=0.01)}
\end{gathered}
$$

- normal force coefficient:

$$
C_{N}=C_{N \alpha} \alpha_{t}+C_{N \delta} \delta_{F}
$$




$$
\begin{gathered}
C_{N \alpha}=C_{N \alpha_{-} W A T} \frac{C_{N \alpha_{-} \text {Prodas }}(M a)}{C_{N \alpha_{-} \text {Prodas }}(M a=0.01)}=\left(6.72+0.16 e^{-\frac{1}{2}\left(\frac{\delta_{F}}{8}\right)^{2}}\right) \frac{C_{N \alpha_{-} \text {Prodas }}(M a)}{C_{N \alpha_{-} \text {Prodas }}(M a=0.01)} \\
C_{N \delta_{1}}=C_{N \delta_{-} W A T} \frac{C_{N \delta_{-} \text {Prodas }}(M a)}{C_{N \delta_{-} \text {Prodas }}(M a=0.01)}=\left(0.45 e^{-\frac{1}{2}\left(\frac{\alpha}{10.5}\right)^{2}}\right) \frac{C_{N \delta_{-} \text {Prodas }}(M a)}{C_{N \delta_{-} \text {Prodas }}(M a=0.01)}
\end{gathered}
$$

- banking moment coefficient:

$$
\begin{aligned}
& C_{m}=C_{m \alpha} \alpha_{t}+C_{m \delta} \delta_{F} \\
& C_{m \alpha}=C_{m \alpha_{-} W A T} \frac{C_{m \alpha_{-} \text {Prodas }}(M a)}{C_{m \alpha_{-} \text {Prodas }}(M a=0.01)}=\left(-8.9+0.8 e^{-\frac{1}{2}\left(\frac{\delta_{F}}{8}\right)^{2}}\right) \frac{C_{m \alpha_{-} \text {Prodas }}(M a)}{C_{m \alpha_{-} \text {Prodas }}(M a=0.01)} \\
& C_{m \delta}=C_{m \delta_{-} W A T} \frac{C_{z a F 2 \_ \text {Prodas }}(M a)}{C_{z a F 2 \_ \text {Prodas }}(M a=0.01)}=\left(3.7 e^{-\frac{1}{2}\left(\frac{\alpha}{10.5}\right)^{2}}\right) \frac{C_{z a F 2 \_ \text {Prodas }}(M a)}{C_{z a F 2 \_ \text {Prodas }}(M a=0.01)}
\end{aligned}
$$

The other coefficients were calculated utilising Prodas software. Their results were obtained in Mach number.

Control laws used in calculations assume the proportional relation between a command signal and the difference between target observation angle in the appropriate plane and the angle of attack:

$$
\delta_{F}=k\left(\alpha-\varphi_{L O C}\right)
$$

For the considered movement in a vertical plane, $O x z$ is:

$$
\alpha=\operatorname{arctg} \frac{W}{U}, \varphi_{L O C}=\operatorname{arctg} \frac{-z_{g_{-} \text {bomba }}(t)}{x_{g_{-} c e l}-x_{g_{-} c e l}(c)}
$$

\section{Results of calculations}

Calculations assumed that a bomb is dropped horizontally from the altitude of 3000 metres and with the speed of $55 \mathrm{~m} / \mathrm{s}$. The bomb released under these conditions falls within 25.74 seconds. The release point is located at the distance of $1258.6 \mathrm{~m}$ from the release point. 
Firstly, the theoretical range of a bomb was estimated. To achieve this objective two extreme deflections of control surfaces $\pm 15^{\circ}$ were adopted. The results of these calculations were presented in figures $3 \div 5$. Fig. 3 shows the obtained flight trajectories of the bomb. It is inferred from them that the range of the bomb is in between 339 and $2441 \mathrm{~m}$. Permanent deflection of control surfaces also affects other flight parameters. Fig. 4 depicts that deflection of control surfaces does change the pitch angle of the bomb. In the case of $\delta=-15^{\circ}$, the pitch angle exceeds $-120^{\circ}$. Fig. 5 presents that the change in the angle of attack of the bomb results in the generation of damped oscillations. The deflection of control surfaces also causes that the determined value of this angle is different. It may, therefore, be stated that even extreme deflections of control surfaces do not cause the bomb to exceed the critical angle of attack. The reasoning shows that the control surfaces will become effective during the whole flight.

Building upon the knowledge of the range of the bomb, one adopted two target locations, where the bomb is to be found:

- target located farther than the release point $(1295.6 \mathrm{~m})$ at a distance of $1800 \mathrm{~m}$,

- target located closer than the release point $(1295.6 \mathrm{~m})$ at a distance of $1000 \mathrm{~m}$.

Below, the most relevant flight parameters are demonstrated, and the obtained results of the simulations are explained.

\section{Target 1800 metres}

Target location at a distance of $1800 \mathrm{~m}$ corresponds approximately to the centre of the forward half of the range. Calculations were made changing the activation time of the flight guidance control system of the bomb. Fig. 6 shows the trajectories obtained for times: $t=0 \mathrm{~s}$ (operation from the moment of release), $10 \mathrm{~s}$, $15 \mathrm{~s}, 16 \mathrm{~s}[1,5,6]$. As we see, all of these times ensure a precise target hit. Fig. 7 presented calculated guidance control parameters necessary to hit the target. It is visible that for the case $t=0 \mathrm{~s}$ between $6.62 \mathrm{~s}$ and $8.65 \mathrm{~s}$, control surfaces are at the angle $\delta=-15^{\circ}$, which causes the 'overbending' of the trajectory to the bottom to create a line of observation (LOC) of a bomb parallel to the bomb axis. For all other times of the activation of the guidance control system, the bomb pitch is so high that the deflection angle of control surfaces is positive to prolong the flight path in the direction of the target. For times $15 \mathrm{~s}$ and $16 \mathrm{~s}$, the deflection angle is so high that the control surfaces are immediately moved to the extreme position $\delta=+15^{\circ}$. In all cases up to now, the deflection of control surfaces results in the substantial decrease of the pitch angle, which was exhibited in fig. 8. The maximum 
instantaneous values of the angle of attack are close to $10^{\circ}$, which is lower than the critical angle of attack of the bomb. It guarantees the effectiveness of guidance.

Now, the issue of the critical time $\boldsymbol{t}_{\boldsymbol{k}}$ will be introduced. It is the longest time starting from the moment of release to the activation of laser illuminator, which ensures a target hit with the specific accuracy $\varepsilon$. For the target located at a distance of $1800 \mathrm{~m}, t_{k r}=16 \mathrm{~s}$. Simulations show that exceeding this time does not enable the bomb to reach the target. Fig. 10 demonstrated flight trajectories for guidance activation times equalling $17 \mathrm{~s}, 18 \mathrm{~s}, 18.5 \mathrm{~s}$ and $19 \mathrm{~s}$. It is already evident that in all of these cases the bomb will not reach the target. As can be easily noted, for time 19s, the flight trajectory of the bomb coincides in practice with the flight path of the unguided bomb. It means that the guidance control system did not start to operate efficiently, which can be proved in fig. 11, where for 19s there is an instantaneous, small command signal. It is due to the characteristics of detectors, which, by high values of target observation angle (angle between the detector axis and its LOC) do not generate a command signal. In the remaining cases, control surfaces will be immediately readjusted at their maximum deflection limit (that is, $\delta=+15^{\circ}$ ), but their effectiveness is not enough to aim at the target.

\section{Target 1000 metres}

Position of a target at a distance of $1000 \mathrm{~m}$ signifies that it is at a distance of $300 \mathrm{~m}$ before the release point of the unguided bomb. Similarly as previously, the simulations were performed by changing the activation time of the guidance control system of the bomb flight. Fig. 12 illustrates flight trajectories obtained for times: $t=0 \mathrm{~s}$ (operation from the moment of release), $10 \mathrm{~s}, 15 \mathrm{~s}, 18 \mathrm{~s}$.

For all of these times, the bomb hits the target. Fig. 13 depicts guidance. It is clear that in each case, the control surface is held at a maximum deflection of $\delta=-15^{\circ}$. After some time, this angle is changed. Guidance affects the pitch angle, which rapidly increases - fig.14. Also in this case the angles of attack change and contribute to damped oscillations - fig. 15 .

The simulations showed that too late activation of guidance control system does not allow to reach the target closer than the release point. It is confirmed by the trajectories visible in fig. 16. They relate to times $18 \mathrm{~s}, 19 \mathrm{~s}, 20 \mathrm{~s}$ and $21 \mathrm{~s}$. For this target location, time $t_{k r}=18 \mathrm{~s}$ is a critical time. For the times bigger than the abovementioned time, there is an immediate maximum deflection of control surfaces at the angle of $\delta=-15^{\circ}$, which does not enable to aim at the target due to the insufficient effectiveness - fig. 17 . 


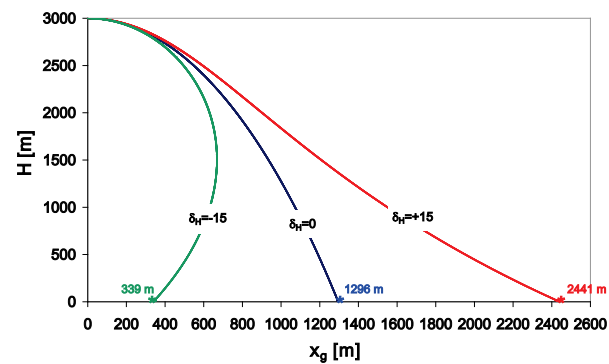

Fig. 3. Trajectory of the unguided bomb and by extreme deflections of control surfaces

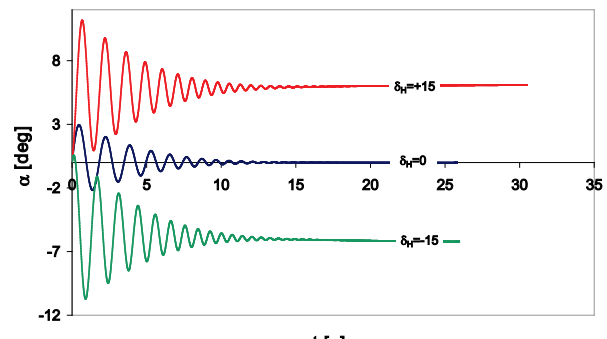

$\mathrm{t}[\mathrm{s}]$

Fig. 5. Angle of attack of the unguided bomb and by extreme deflections of control surfaces

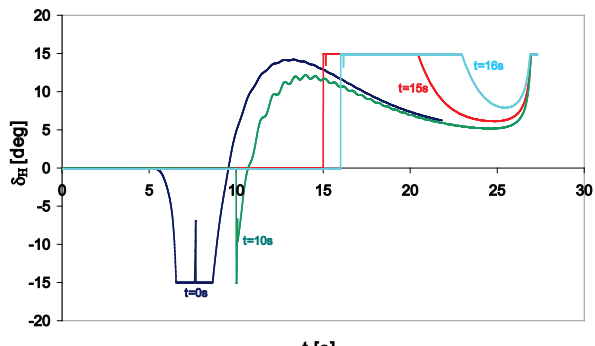

$t[s]$

Fig. 7. Bomb guidance by reaching the target situated farther than the release point

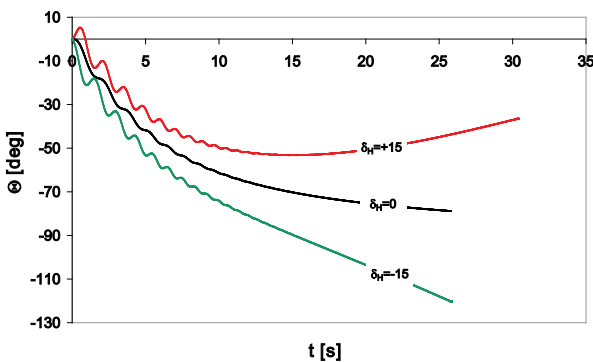

Fig. 4. Pitch angle of the unguided bomb and by extreme deflections of control surfaces

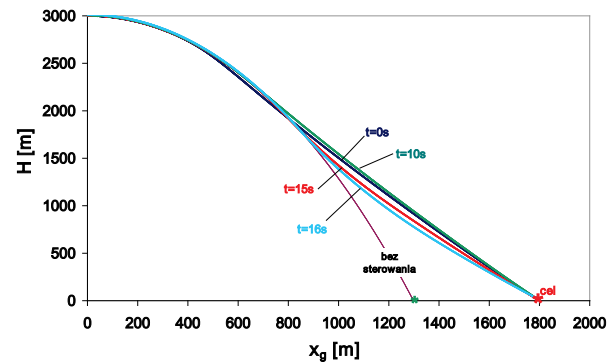

Fig. 6. Trajectory of the bomb reaching the target situated farther than the release point

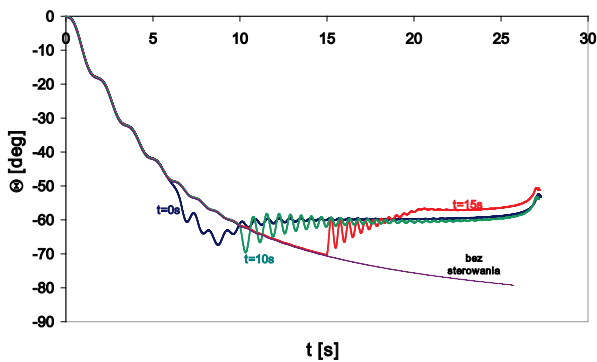

Fig. 8. Pitch angle a bomb reaching the target situated farther than the release point 


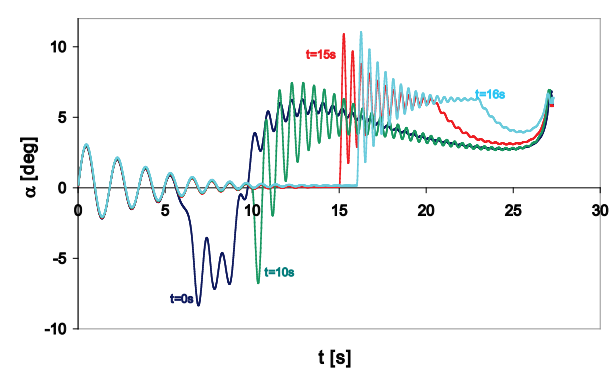

Fig. 9. Angle of attack of a bomb by reaching the target situated farther than the release point

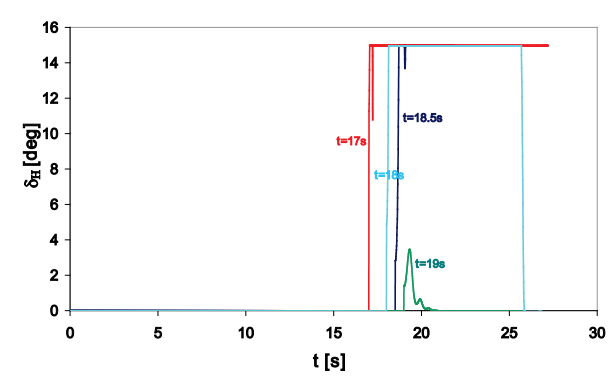

Fig. 11. Trajectory of a bomb in the absence of reaching the target situated farther than the release point

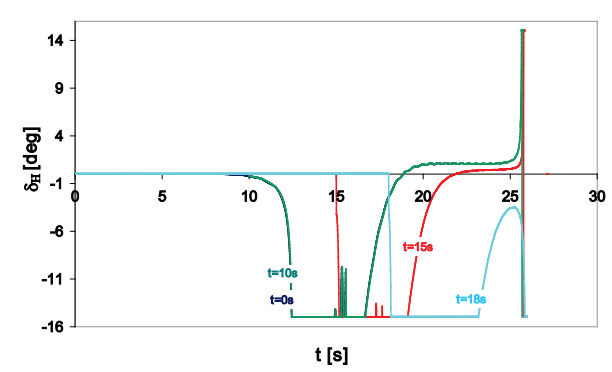

Fig. 13. Bomb guidance by reaching the target situated closer than the release point

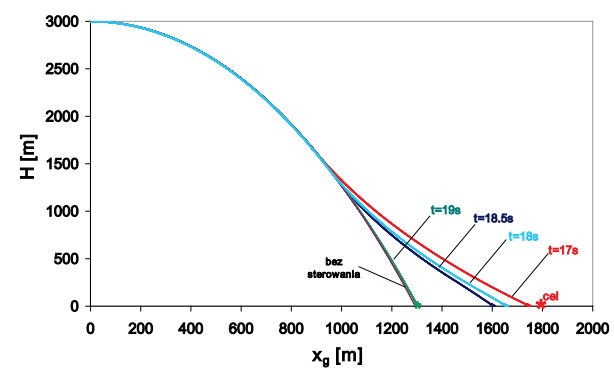

Fig. 10. Trajectory of a bomb in the absence of reaching the target situated farther than the release point

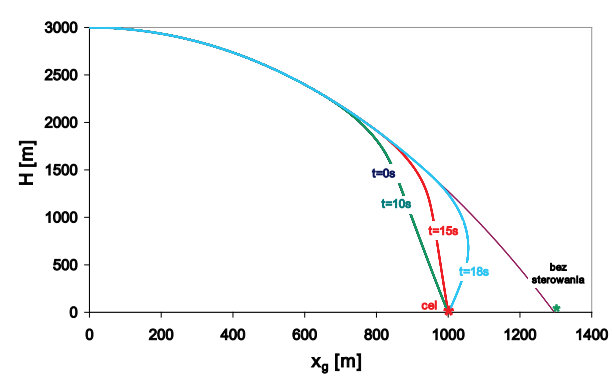

Fig. 12. Trajectory of a bomb by reaching the target situated closer than the release point

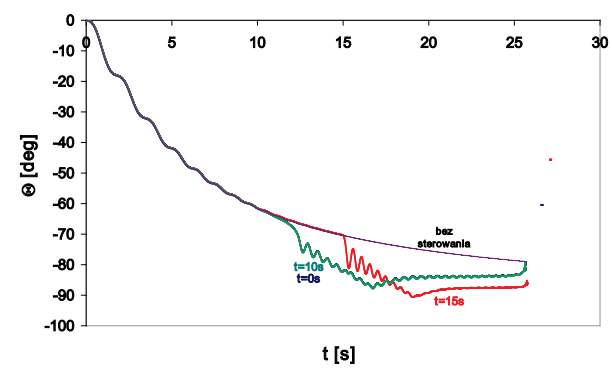

Fig. 14. Pitch angle of a bomb b reaching the target situated closer than the release point 


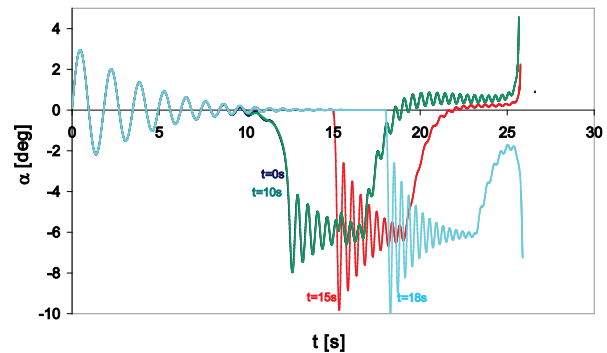

Fig. 15. Angle of attack of a bomb by reaching the target situated closer than the release point

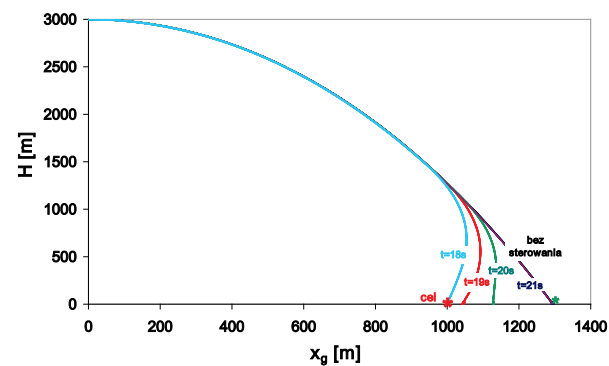

Fig. 16. Trajectory of a bomb in the absence o reaching the target situated closer than the release point

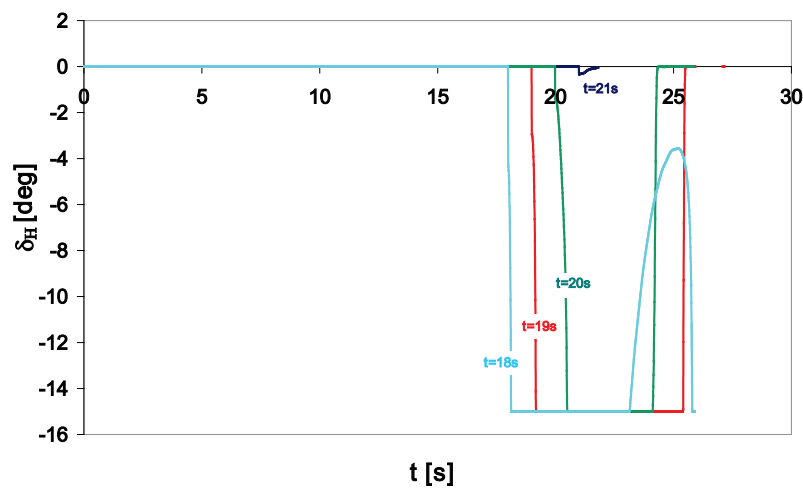

Fig. 17. Bomb guidance by reaching the target situated closer than the release point

\section{Conclusions}

As it was defined previously, the critical time $t_{k r}$ is the longest time from the moment of release to the activation of laser illuminator which ensures hitting the target with the given accuracy $\varepsilon$. Calculations were made by changing the location of the aiming point by $100 \mathrm{~m}$ within $400 \div 2400 \mathrm{~m}$ situated in the range adopting that the hit accuracy is $\varepsilon=5 \mathrm{~m}$. The table below demonstrates the obtained results. Simulations showed that the closest target location, which is possible to be reached, is $890 \mathrm{~m}$ and the farthest $-2300 \mathrm{~m}$. The critical time was determined with the accuracy of 0.5 s. Fig. 18 depicts the dependence between target location and critical time. 


\begin{tabular}{|c|c|c|c|c|c|c|c|}
\hline $\begin{array}{c}\mathrm{Xg}_{\mathrm{g} \_c e l u} \\
{[\mathrm{~m}]}\end{array}$ & $\begin{array}{r}t_{k r} \\
{[\mathrm{~s}]}\end{array}$ & $\begin{array}{c}\mathrm{Xg}_{\mathrm{g} \_ \text {celu }} \\
{[\mathrm{m}]}\end{array}$ & $\begin{array}{r}t_{k r} \\
{[\mathrm{~s}]} \\
\end{array}$ & $\begin{array}{c}\mathrm{Xg}_{\mathrm{g}} \text { celu } \\
{[\mathrm{m}]}\end{array}$ & $\begin{array}{l}\mathrm{t}_{\mathrm{kr}} \\
{[\mathrm{s}]}\end{array}$ & $\begin{array}{c}\mathrm{Xg}_{\mathrm{g}} \text { celu } \\
{[\mathrm{m}]}\end{array}$ & $\begin{array}{l}t_{\mathrm{kr}} \\
{[\mathrm{s}]}\end{array}$ \\
\hline 400 & - & 900 & 14 & 1400 & 22 & 1900 & 15 \\
\hline 500 & - & 1000 & 18 & 1500 & 20 & 2000 & 13 \\
\hline 600 & - & 1100 & 20 & 1600 & 18.5 & 2100 & 11 \\
\hline 700 & - & 1200 & 22.3 & 1700 & 17 & 2200 & 10 \\
\hline 890 & 10 & 1300 & 25.74 & 1800 & 16 & 2300 & - \\
\hline
\end{tabular}

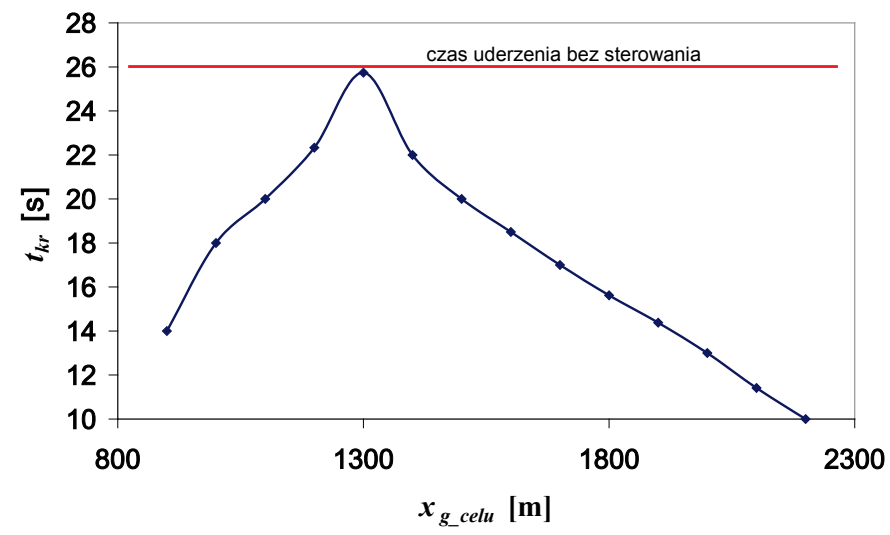

Fig. 18. Critical time of the activation of guidance control system

\section{References}

1. Jankowski A., Kowalski M.: Start-up processes' efficiency of turbine jet engines, Journal of KONBiN, 40 (1), 1 December 2016.

2. Kowaleczko G., Dębiński J., Kwaśniak T.: Model matematyczny bomby korygowanej, opracowanie wewnętrzne ITWL, Warszawa 2017.

3. Kowaleczko G., Żyluk A., Pietraszek M., Olejniczak E.: Evaluation of the Possibility of Bomb Flight Control, Journal of KONES, Vol. 22, No. 3, 2015.

4. Kowaleczko G.: Modelowanie dynamiki lotu obiektów latających, Wyd. ITWL, Warszawa 2018.

5. Kowalski M., Sulkowski J.: Statistical Verification of experimental tests to determine geographical positions of objects, Journal of $\operatorname{KONBiN,~2,~} 3(14,15)$, 2010 .

6. Kowalski M.: Phase mapping in the diagnosing of a turbojet engine, Journal of Theoretical and Applied Mechanics, Vol. 50, Iss. 4, 2012. 
7. McCoy R.L.: Modern Exterior Ballistics, McGraw-Hill Book Company Inc., New York 1969.

8. $\quad$ PRODAS Software v.3, Arrow Tech Associates Inc., 2008.

9. Sołowiej E., Hrapow A.: Dinamika system nawiedenija uprawliajemych awiabomb, Rosyjska Akademia Rakietowych i Artyleryjskich Nauk, Moskwa 2006. 


\section{ANALIZA WPLYWU CZASU PODŚWIETLANIA CELU NA EFEKTYWNOŚĆ UKŁADU KOREKCJI LOTU}

\section{Opis modelu symulacyjnego}

Celem badań symulacyjnych była ocena w jaki sposób czas aktywowania układu korekcji lotu bomby wpływa na celność jej trafienia w podświetlony cel. Obliczenia przeprowadzono wykorzystując model matematyczny ruchu bomby sterowanej, na który składają się równania ruchu uzupełnione równaniami określającymi prawa sterowania $[2,3,4,7,9]$.

Wprowadza się oznaczenia:

- $U, V, W$ - składowe prędkość bomby w układzie $O x y z$ związanym z bombą,

- $P, Q, R$ - prędkość kątowa układu związanego z bombą,

- $\Psi, \Theta$ i $\Phi$ - kąty bomby określające odpowiednio jej: odchylenie, pochylenie, przechylenie,

- $x_{g}, y_{g}, z_{g}$ - współrzędne określające położenie bomby względem układu ziemskiego $O_{g} x_{g} y_{g} z_{g}$,

- $m, I_{x}, I=I_{y}=I_{z}-$ masa i momenty bezwładności bomby.

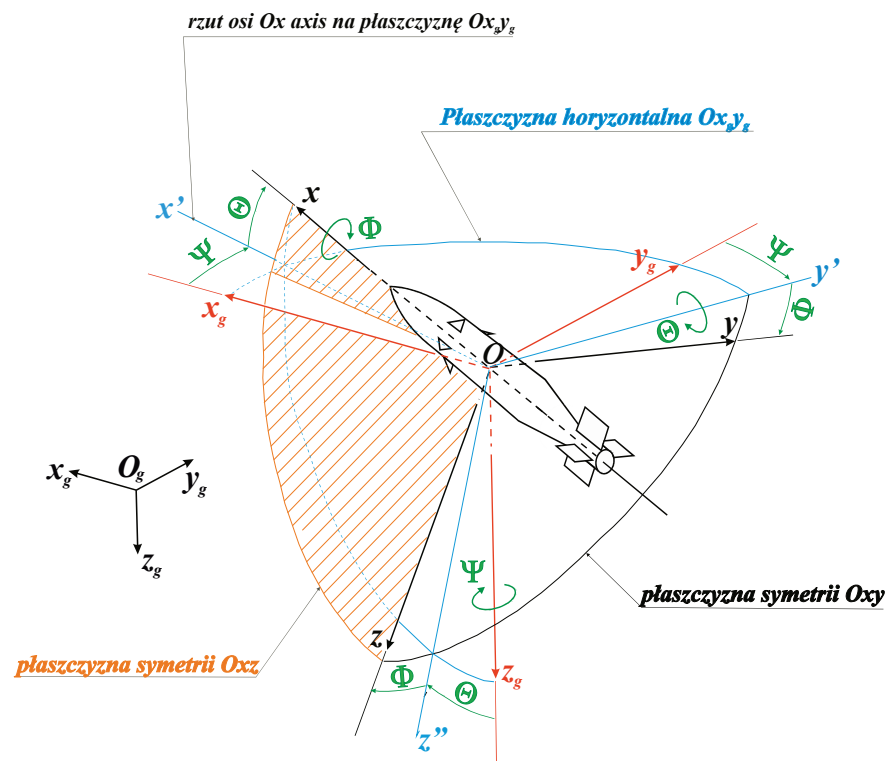

Rys. 1. Układy współrzędnych Oxgygzg i Oxyz 
Ruch bomby opisują równania stanowiące układ dwunastu równań różniczkowych:

$$
\mathbf{A} \dot{\mathbf{x}}=\mathbf{f}
$$

gdzie $\mathbf{x}$ jest wektorem parametrów lotu:

$$
\mathbf{x}=\left[U, V, W, P, Q, R, \Phi, \Theta, \Psi, x_{O}, y_{O}, z_{O}\right]^{T}
$$

Niezerowe elementy macierzy A są równe:

$$
\begin{aligned}
& A_{11}=m, A_{22}=m, A_{33}=m, \\
& A_{44}=I_{x}, A_{55}=I, A_{66}=I
\end{aligned}
$$

Natomiast wektor $\mathbf{f}$ jest określony następująco:

$$
\begin{gathered}
f_{1}=F_{x}+m(R V-Q W) \\
f_{2}=F_{y}+m(P W-R U) \\
f_{3}=F_{z}+m(Q U-P V) \\
f_{4}=M_{x} \\
f_{5}=M_{y}+P R\left(I-I_{x}\right) \\
f_{6}=M_{z}+P Q\left(I_{x}-I\right) \\
f_{7}=P+(Q \sin \Phi+R \cos \Phi) \tan \Theta \\
f_{8}=Q \cos \Phi-R \sin \Phi \\
f_{9}=(Q \sin \Phi+R \cos \Phi) / \cos \Theta
\end{gathered}
$$




$$
\begin{aligned}
f_{10}= & U \cos \Psi \cos \Theta+V(\cos \Psi \sin \Theta \sin \Phi-\sin \Psi \cos \Phi)+ \\
& +W(\cos \Psi \sin \Theta \cos \Phi+\sin \Psi \sin \Phi) \\
f_{11}= & U \sin \Psi \cos \Theta+V(\sin \Psi \sin \Theta \sin \Phi+\cos \Psi \cos \Phi)+ \\
& +W(\sin \Psi \sin \Theta \cos \Phi-\cos \Psi \sin \Phi) \\
& f_{12}=-U \sin \Theta+V \cos \Theta \sin \Phi+W \cos \Theta \cos \Phi
\end{aligned}
$$

Na bombę działają siły: ciężkości $\mathbf{Q}$ oraz siły aerodynamiczne i momenty aerodynamiczne. Rys. 2 przedstawia schemat sił i momentów aerodynamicznych. Dokładny sposób ich obliczenia opisano w [4].

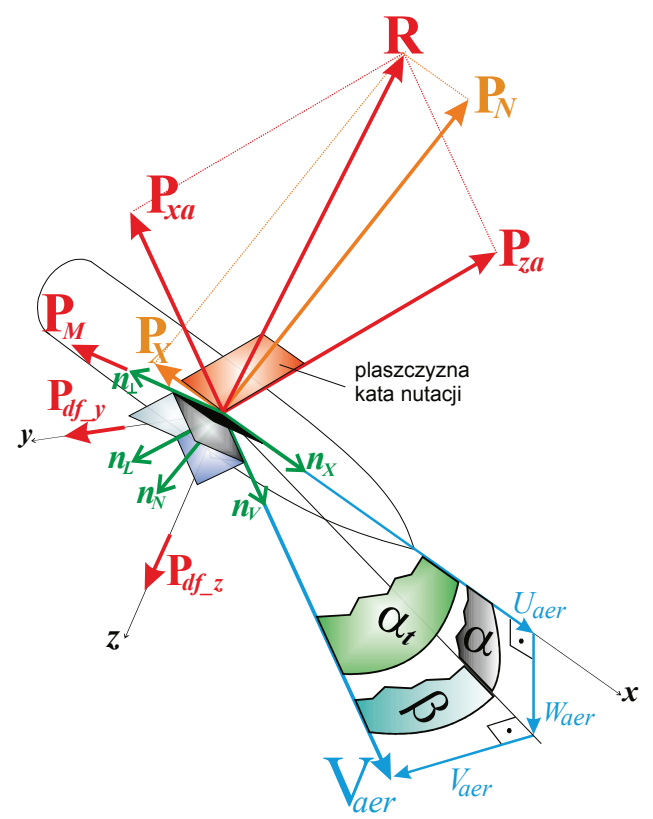

Rys. 2. Układy współrzędnych $\mathrm{Ox}_{\mathrm{g}} \mathrm{y}_{\mathrm{g}} \mathrm{z}_{\mathrm{g}}$ i Oxyz

- Siła ciężkości ma składowe:

$$
Q_{x}=-m g \sin \Theta, Q_{y}=m g \cos \Theta \sin \Phi, Q_{z}=m g \cos \Theta \cos \Phi
$$

Wartości sił i momentów aerodynamicznych oblicza się z wzorów:

- Siła osiowa: 


$$
P_{X}=C_{X} \frac{\rho\left|\mathbf{V}_{a e r}\right|^{2}}{2} S
$$

- Siła normalna:

$$
P_{N}=C_{N} \frac{\rho\left|\mathbf{V}_{a e r}\right|^{2}}{2} S
$$

- Statyczny moment pochylający:

$$
M_{s t}=C_{m_{-} s t} \frac{\rho\left|\mathbf{V}_{a e r}\right|^{2}}{2} S d
$$

- Tłumiący moment pochylający:

$$
M_{d m}=\left(C_{m_{-} q}+C_{m_{-} \dot{\alpha}}\right) \frac{\rho\left|\mathbf{V}_{a e r}\right|}{2} S d^{2}
$$

- Thumiący moment przechylający:

$$
M_{p}=C_{p}\left(\frac{P d}{\left|\mathbf{V}_{a e r}\right|}\right) \frac{\rho\left|\mathbf{V}_{a e r}\right|^{2}}{2} S d
$$

W obliczeniach wykorzystano charakterystyki bomby otrzymane w trakcie badań w tunelu aerodynamicznym, które przeliczono uwzględniając wpływ liczby Macha. W tym celu uwzględniono charakterystyki tej samej bomby wyznaczone oprogramowaniem Prodas [8]. Podstawowe zależności użyte do obliczenia tych charakterystyk $\mathrm{w}$ funkcji kąta nutacji $\alpha_{t}$ i katów wychylenia sterów $\delta_{F}$ są następujące:

- współczynnik siły oporu:

$$
\begin{gathered}
C_{X}=C_{X 0}+C_{X \alpha 2}\left(\sin \alpha_{t}\right)^{2} \\
C_{X 0}=C_{X 0 \_ \text {WAT }} \frac{C_{X 0 \_ \text {Prodas }}(M a)}{C_{X 0 \_ \text {Prodas }}(M a=0.01)}=\left(0.227+0.036 \frac{|\delta|}{15}\right) \frac{C_{X 0 \_ \text {Prodas }}(M a)}{C_{X 0 \_ \text {Prodas }}(M a=0.01)}
\end{gathered}
$$




$$
C_{X \alpha 2}=C_{X \alpha 2 \_W A T} \frac{C_{X \alpha 2 \_ \text {Prodas }}(M a)}{C_{X \alpha 2_{2} \text { Prodas }}(M a=0.01)}=\left[\left(6.59-0.15 \frac{|\delta|}{15}\right) \alpha^{2}\right] \frac{C_{X \alpha 2 \_ \text {Prodas }}(M a)}{C_{X \alpha 2_{2} \text { Prodas }}(M a=0.01)}
$$

- współczynnik siły normalnej:

$$
\begin{gathered}
C_{N}=C_{N \alpha} \alpha_{t}+C_{N \delta} \delta_{F} \\
C_{N \alpha}=C_{N \alpha_{-} W A T} \frac{C_{N \alpha_{-} \text {Prodas }}(M a)}{C_{N \alpha_{-} \text {Prodas }}(M a=0.01)}=\left(6.72+0.16 e^{-\frac{1}{2}\left(\frac{\delta_{F}}{8}\right)^{2}}\right) \frac{C_{N \alpha_{-} \text {Prodas }}(M a)}{C_{N \alpha_{-} \text {Prodas }}(M a=0.01)} \\
C_{N \delta}=C_{N \delta_{-} W A T} \frac{C_{N \delta_{-} \text {Prodas }}(M a)}{C_{N \delta_{-} \text {Prodas }}(M a=0.01)}=\left(0.45 e^{-\frac{1}{2}\left(\frac{\alpha}{10.5}\right)^{2}}\right) \frac{C_{N \delta_{-} \text {Prodas }}(M a)}{C_{N \delta_{-} \text {Prodas }}(M a=0.01)}
\end{gathered}
$$

- współczynnik momentu pochylającego:

$$
\begin{aligned}
& C_{m}=C_{m \alpha} \alpha_{t}+C_{m \delta} \delta_{F} \\
& C_{m \alpha}=C_{m \alpha_{-} W A T} \frac{C_{m \alpha_{-} \text {Prodas }}(M a)}{C_{m \alpha_{-} \text {Prodas }}(M a=0.01)}=\left(-8.9+0.8 e^{-\frac{1}{2}\left(\frac{\delta_{F}}{8}\right)^{2}}\right) \frac{C_{m \alpha_{-} \text {Prodas }}(M a)}{C_{m \alpha_{-} \text {Prodas }}(M a=0.01)} \\
& C_{m \delta}=C_{m \delta_{-} W A T} \frac{C_{z a F 2 \_ \text {Prodas }}(M a)}{C_{z a F 2 \_ \text {Prodas }}(M a=0.01)}=\left(3.7 e^{-\frac{1}{2}\left(\frac{\alpha}{10.5}\right)^{2}}\right) \frac{C_{z a F 2 \_P r o d a s}(M a)}{C_{z a F 2 \_ \text {Prodas }}(M a=0.01)}
\end{aligned}
$$

Pozostałe współczynniki obliczono używając oprogramowania Prodas. Otrzymano ich przebiegi w funkcji liczby Macha.

Prawa sterowania zastosowane $\mathrm{w}$ obliczeniach zakładają proporcjonalną relację pomiędzy sygnałem sterującym i różnicą pomiędzy kątem obserwacji celu w odpowiedniej płaszczyźnie i kątem natarcia:

$$
\delta_{F}=k\left(\alpha-\varphi_{L O C}\right)
$$

Dla rozpatrywanego ruchu w płaszczyźnie pionowej $O x z$ jest: 


$$
\alpha=\operatorname{arctg} \frac{W}{U}, \varphi_{L O C}=\operatorname{arctg} \frac{-z_{g_{-} b o m b a}(t)}{x_{g_{-} c e l}-x_{g_{-} c e l}(c)}
$$

\section{Wyniki obliczeń}

W obliczeniach założono, że bomba zrzucana jest poziomo z wysokości $3000 \mathrm{~m}$ z prędkością $55 \mathrm{~m} / \mathrm{s}$. Bomba zrzucona w tych warunkach spada w $25.74 \mathrm{~s}$. Punkt upadku leży w odległości $1295.6 \mathrm{~m}$ od punktu zrzutu.

Początkowo oszacowano teoretyczny przedział donośności bomby. W tym celu założono dwa skrajne wychylenia sterów $\pm 15^{\circ}$. Wyniki obliczeń pokazano na rysunkach 3-5. Na rys. 3 pokazano uzyskane trajektorie bomby. Wynika z nich, że donośność bomby leży w przedziale 339-2441 m. Stałe wychylenie sterów ma też wpływ na pozostałe parametry lotu. $Z$ rys. 4 widać, że wychylenie sterów istotnie zmienia kąt pochylenia bomby. W przypadku $\delta=-15^{\circ}$ kąt pochylenia przekracza $-120^{\circ}$. Rys. 5 pokazuje, że zmiana kąta natarcia bomby ma charakter thumionych oscylacji. Wychylenie sterów powoduje jednocześnie, że ustalona wartość tego kąta jest różna. Można też ocenić, że nawet skrajne wychylenia sterów nie powodują przekroczenia przez bombę krytycznego kąta natarcia. Można stąd wnioskować, że stery pozostaną skuteczne podczas całego lotu.

W oparciu o znajomość zakresu donośności bomby założono dwa położenia celu, w który bomba ma trafić:

- cel położony dalej niż punkt upadku (1295.6 m) w odległości 1800 m,

- cel położony bliżej niż punkt upadku (1295.6 m) w odległości $1000 \mathrm{~m}$.

Poniżej zostaną pokazane najistotniejsze parametry lotu i omówione otrzymane wyniki symulacji.

\section{Cel 1800 metrów}

Położenie celu w odległości $1800 \mathrm{~m}$ odpowiada w przybliżeniu środkowi przedniej połowy zasięgu donośności. Obliczenia przeprowadzono zmieniając czas uruchomienia układu sterowania lotem bomby. Na rys. 6 pokazano trajektorie uzyskane dla czasów: $t=0 \mathrm{~s}$ (działanie od chwili zrzutu), $10 \mathrm{~s}, 15 \mathrm{~s}, 16 \mathrm{~s}[1,5,6]$. Jak widać wszystkie te czasy zapewniaja precyzyjne trafienie w cel. Na rys. 7 przedstawiono wyliczone sterowania konieczne do trafienia w cel. Widać, że dla przypadku $t=0$ s pomiędzy $6.62 \mathrm{~s}$ i $8.65 \mathrm{~s}$ stery ustawiane są na kąt $\delta=-15^{\circ}$, co powoduje ,doginanie" trajektorii do dołu w celu ustawienia linii obserwacji bomby (LOC) równolegle do jej osi. Dla wszystkich pozostałych czasów włączenia układu sterowania pochylenie bomby jest na tyle duże, że kąt wychylenia sterów jest 
dodatni, aby wydłużyć tor lotu w kierunku celu. Dla czasów 15 s i 16 s kąt pochylenia jest tak duży, że stery natychmiast są przestawiane w skrajne położenie $\delta=+15^{\circ}$. We wszystkich rozpatrywanych przypadkach wychylenie sterów powoduje istotne zmniejszenie kąta pochylenia, co pokazano na rys. 8 . Maksymalne chwilowe wartości kąta natarcia są bliskie wartości $10^{\circ}$, która jest mniejsza niż krytyczny kąt natarcia bomby. Zapewnia to skuteczność sterowania.

Czas krytyczny $\boldsymbol{t}_{\boldsymbol{k} r}$ jest to najdłuższy czas od momentu zrzutu do uruchomienia podświetlacza laserowego, który zapewnia trafienie w cel z określoną dokładnością $\varepsilon$. Dla celu położonego w odległości $1800 \mathrm{~m} t_{k r}=16 \mathrm{~s}$. Symulacje pokazują, że jego przekroczenie nie pozwala na osiagnięcie celu przez bombę. Na rys. 10 pokazano trajektorie dla czasów uruchomienia sterowania równych: $17 \mathrm{~s}, 18 \mathrm{~s}, 18.5 \mathrm{~s}$ i $19 \mathrm{~s}$. Widać, że w żadnym z tych przypadków bomba nie osiagnie celu. Łatwo również zauważyć, iż dla czasu $19 \mathrm{~s}$ trajektoria bomby pokrywa się w praktyce z trajektorią bomby niesterowanej. Oznacza to, że układ sterowania nie zaczął efektywnie pracować, potwierdza to rys. 11, gdzie dla 19 s pojawia się chwilowy, niewielki sygnał sterujący. Wynika to z charakterystyki detektorów, które przy znacznych wartościach kąta obserwacji celu (kąt pomiędzy osią detektora i jego LOC) nie generują sygnału sterowania. W pozostałych przypadkach stery zostają natychmiast przestawione na maksymalne wychylenie $\delta=+15^{\circ}$, ale ich efektywność nie pozwala na trafienie w cel.

\section{Cel 1000 metrów}

Położenie celu w odległości 1000 m oznacza, że leży on w odległości 300 m przed punktem upadku bomby niesterowanej. Podobnie jak poprzednio symulacje przeprowadzono zmieniając czas uruchomienia układu sterowania lotem bomby. Na rys. 12 pokazano trajektorie uzyskane dla czasów: $t=0$ s (działanie od chwili zrzutu), $10 \mathrm{~s}, 15 \mathrm{~s}, 18 \mathrm{~s}$.

Dla wszystkich tych czasów osiagnięto trafienie bomby w cel. Rys. 13 ilustruje sterowanie. Widać, że w każdym przypadku ster jest przestawiany na maksymalne wychylenie $\delta=-15^{\circ}$. Po pewnym czasie kąt ten jest zmieniany. Sterowanie wpływa na kąt pochylenia, który gwałtownie rośnie - rys. 14. Również w tym przypadku kąty natarcia zmieniają się w sposób oscylacyjny tłumiony - rys. 15.

Symulacje pokazały, że zbyt późne włączenie układu sterowania nie pozwala osiagnąć celu położonego bliżej niż punkt upadku. Ilustrują to trajektorie przedstawione na rys. 16 . Odnoszą się one do czasów 18 s, 19 s, 20 s oraz $21 \mathrm{~s}$. Dla tego położenia celu czas $t_{k r}=18 \mathrm{~s}$ jest czasem krytycznym. Dla czasów większych od niego następuje natychmiastowe maksymalne wychylenie sterów na kąt $\delta=-15^{\circ}$ co nie pozwala jednak na trafienie, ze względu na niewystarczającą efektywność rys. 17 . 


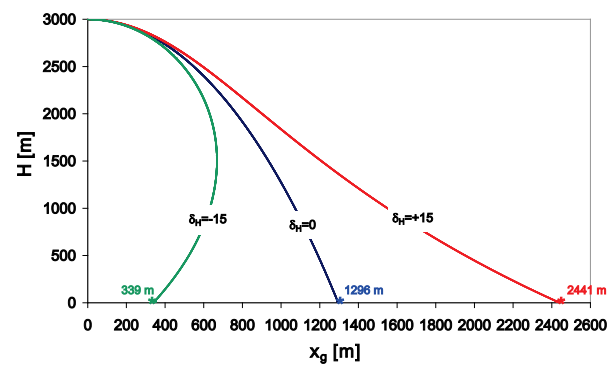

Rys. 3. Trajektoria bomby bez sterowania i przy skrajnych wychyleniach sterów

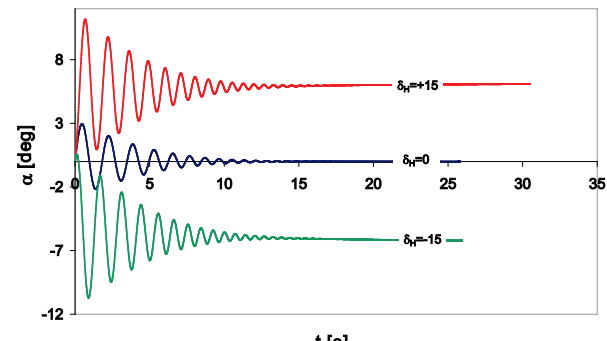

$t$

Rys. 5. Kąt natarcia bomby bez sterowania i przy skrajnych wychyleniach sterów

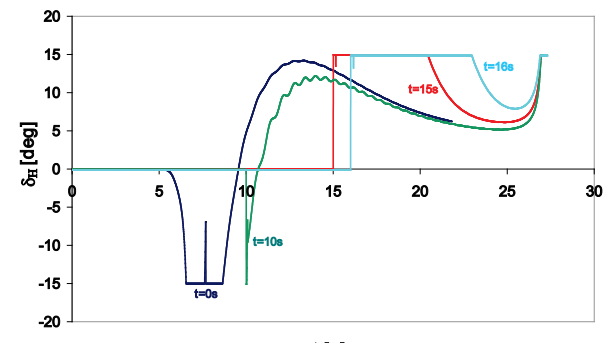

$t[s]$

Rys. 7. Sterowanie bombą przy trafianiu w cel leżący dalej niż punkt upadku

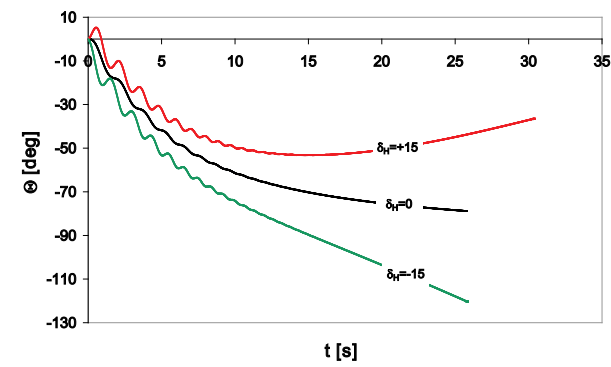

Rys. 4. Kąt pochylenia bomby bez sterowania i przy skrajnych wychyleniach sterów

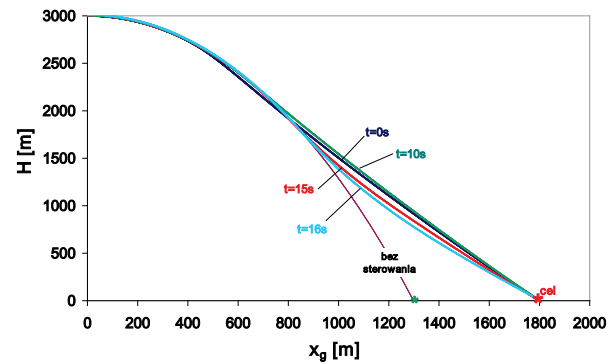

Rys. 6. Trajektoria bomby przy trafianiu w cel leżący dalej niż punkt upadku

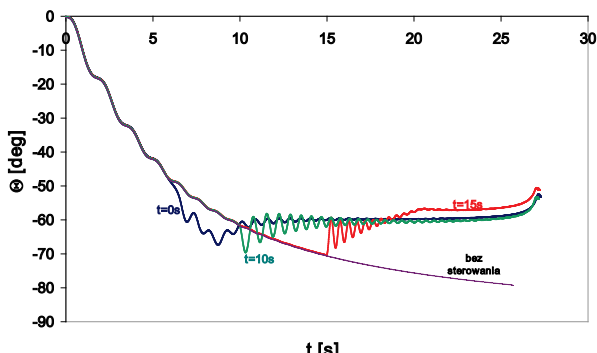

$\mathrm{t}[\mathrm{s}]$

Rys. 8. Kąt pochylenia bomby przy trafianiu w cel leżący dalej niż punkt upadku 


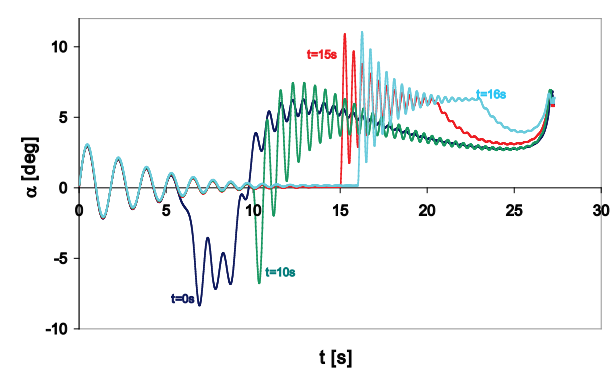

Rys. 9. Kąt natarcia bomby przy trafieniu w cel leżący dalej niż punkt upadku

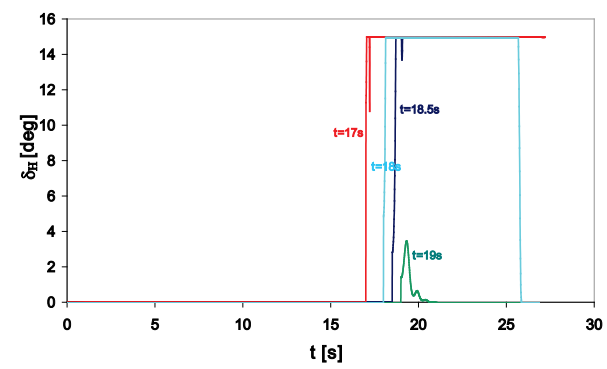

Rys. 11. Sterowanie bombą przy braku trafienia w cel leżący dalej niż punkt upadku

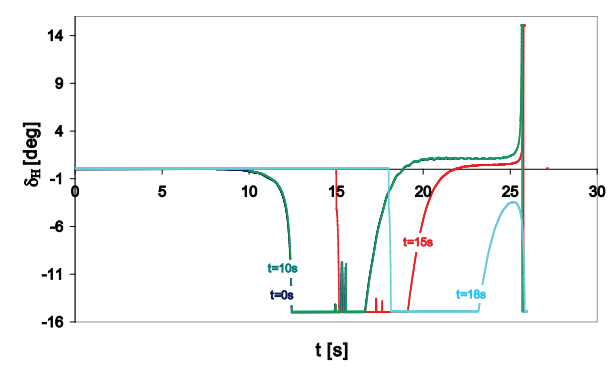

Rys. 13. Sterowanie bombą przy trafianiu w cel leżący bliżej niż punkt upadku

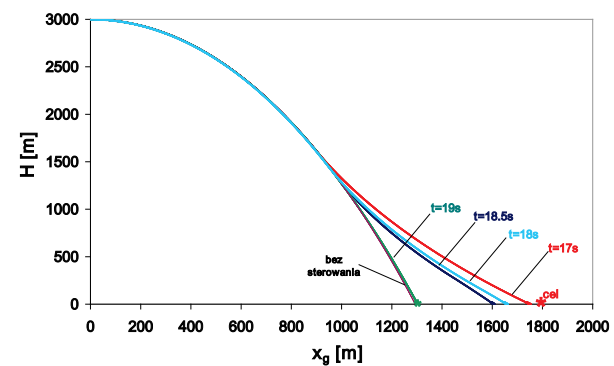

Rys. 10. Trajektoria bomby przy braku trafienia w cel leżący dalej niż punkt upadku

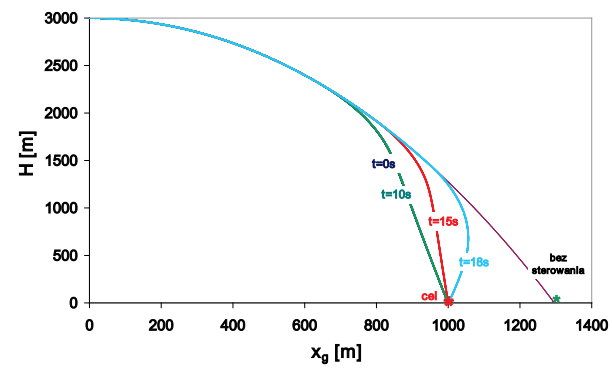

Rys. 12. Trajektoria bomby przy trafianiu w cel leżący bliżej niż punkt upadku

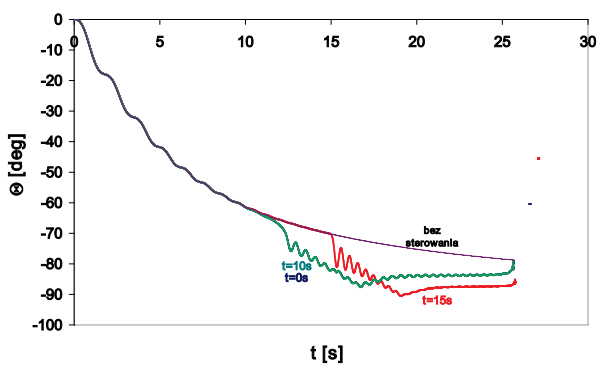

Rys. 14. Kąt pochylenia bomby przy trafianiu w cel leżący bliżej niż punkt upadku $t$ 


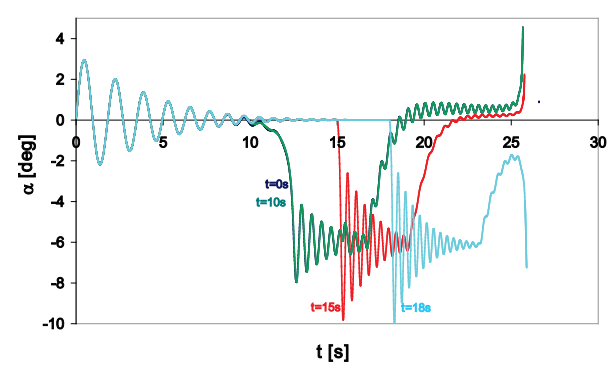

Rys. 15. Kąt natarcia bomby przy trafieniu w cel leżący bliżej niż punkt upadku

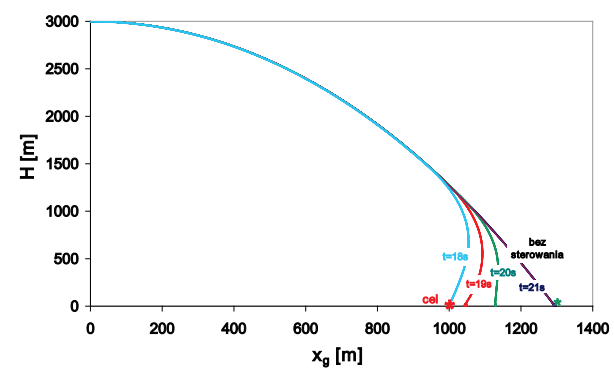

Rys. 16. Trajektoria bomby przy braku trafienia $\mathrm{w}$ cel leżący bliżej niż punkt upadku

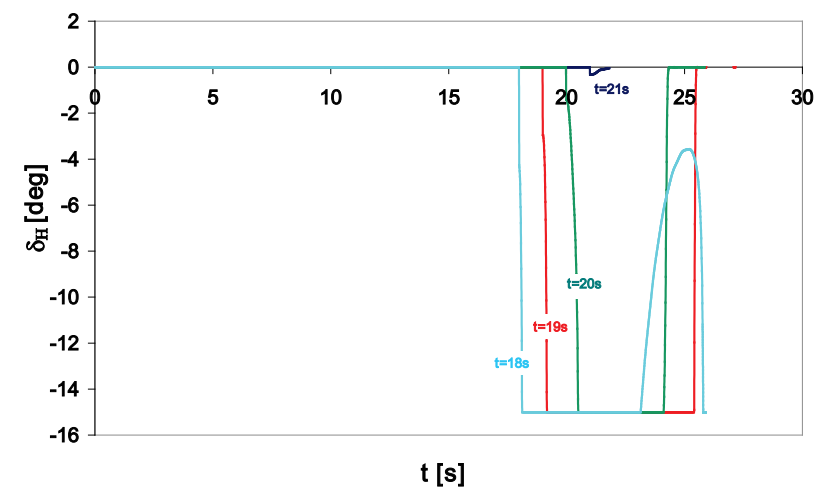

Rys. 17. Sterowanie bombą przy trafianiu w cel leżący bliżej niż punkt upadku

\section{Wnioski}

Czas krytyczny $t_{k r}$, jak zdefiniowano wcześniej, to najdłuższy czas od momentu zrzutu do uruchomienia podświetlacza laserowego, który zapewnia trafienie w cel z określoną dokładnością $\varepsilon$. Przeprowadzono obliczenia zmieniając położenie punktu celowania co $100 \mathrm{~m}$ w zakresie 400-2400 m mieszczącym się w przedziale donośności przy założeniu, że dokładność trafienia wynosi $\varepsilon=5 \mathrm{~m}$. W tabeli poniżej podano otrzymane wyniki. Symulacje pokazały, że najbliższe możliwe do trafienia położenie celu wynosi $890 \mathrm{~m}$, a najdalsze $2300 \mathrm{~m}$. Czas krytyczny wyznaczano z dokładnością do około $0.5 \mathrm{~s}$. Na rys. 18 pokazano zależność pomiędzy położeniem celu, a czasem krytycznym. 


\begin{tabular}{|c|c|c|c|c|c|c|c|}
\hline $\begin{array}{c}\mathrm{Xg}_{\mathrm{g} \_c e l u} \\
{[\mathrm{~m}]}\end{array}$ & $\begin{array}{r}t_{k r} \\
{[s]}\end{array}$ & $\begin{array}{c}\mathrm{Xg}_{\mathrm{g} \_ \text {celu }} \\
{[\mathrm{m}]}\end{array}$ & $\begin{array}{l}t_{k r} \\
{[\mathrm{~s}]}\end{array}$ & $\begin{array}{c}\mathrm{Xg}_{\mathrm{g} \_ \text {celu }} \\
{[\mathrm{m}]}\end{array}$ & $\begin{array}{l}t_{k r} \\
{[s]}\end{array}$ & $\begin{array}{c}\mathrm{Xg}_{\mathrm{g} \_ \text {celu }} \\
{[\mathrm{m}]}\end{array}$ & $\begin{array}{l}t_{\mathrm{kr}} \\
{[\mathrm{s}]}\end{array}$ \\
\hline 400 & - & 900 & 14 & 1400 & 22 & 1900 & 15 \\
\hline 500 & - & 1000 & 18 & 1500 & 20 & 2000 & 13 \\
\hline 600 & - & 1100 & 20 & 1600 & 18.5 & 2100 & 11 \\
\hline 700 & - & 1200 & 22.3 & 1700 & 17 & 2200 & 10 \\
\hline 890 & 10 & 1300 & 25.74 & 1800 & 16 & 2300 & - \\
\hline
\end{tabular}

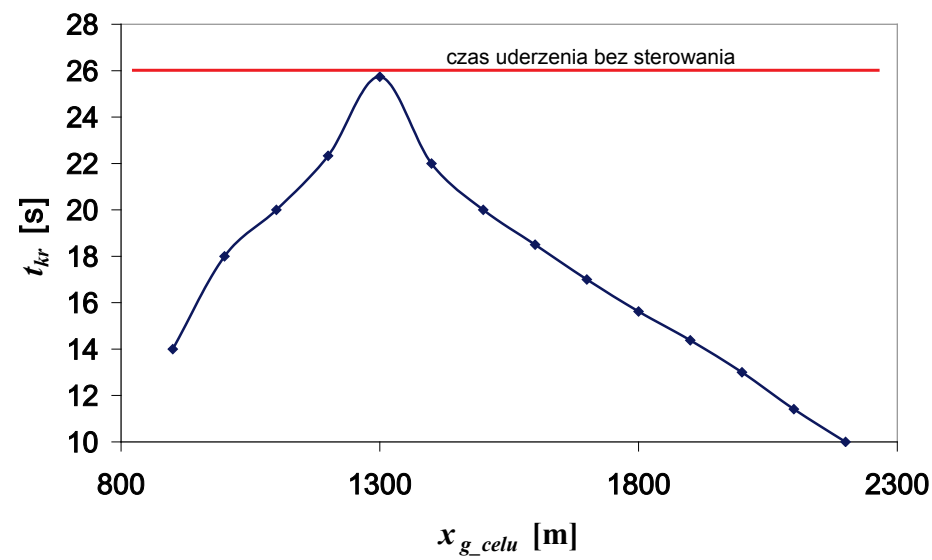

Rys.18. Czas krytyczny uruchomienia układu sterowania

\section{Literatura}

1. Jankowski A., Kowalski M.: Start-up processes' efficiency of turbine jet engines, Journal of KONBiN, 40 (1), 1 December 2016.

2. Kowaleczko G., Dębiński J., Kwaśniak T.: Model matematyczny bomby korygowanej, opracowanie wewnętrzne ITWL, Warszawa 2017.

3. Kowaleczko G., Żyluk A., Pietraszek M., Olejniczak E.: Evaluation of the Possibility of Bomb Flight Control, Journal of KONES, Vol. 22, No. 3, 2015.

4. Kowaleczko G.: Modelowanie dynamiki lotu obiektów latających, Wyd. ITWL, Warszawa 2018. 
5. Kowalski M., Sulkowski J.: Statistical Verification of experimental tests to determine geographical positions of objects, Journal of $\operatorname{KONBiN,~2,~} 3(14,15) 2010$.

6. Kowalski M.: Phase mapping in the diagnosing of a turbojet engine, Journal of Theoretical and Applied Mechanics, Vol. 50, Iss. 4, 2012.

7. McCoy R.L.: Modern Exterior Ballistics, McGraw-Hill Book Company Inc., New York 1969.

8. PRODAS Software v.3, Arrow Tech Associates Inc., 2008.

9. Sołowiej E., Hrapow A.: Dinamika system nawiedenija uprawliajemych awiabomb, Rosyjska Akademia Rakietowych i Artyleryjskich Nauk, Moskwa 2006. 